\title{
Mudflat/distal fan and shallow lake sedimentation (upper Vallesian-Turolian) in the Tianshui Basin, Central China: Evidence against the late Miocene eolian loess
}

\author{
A.M. Alonso-Zarza ${ }^{\mathrm{a}, *}$, Z. Zhao $^{\mathrm{b}}$, C.H. Song ${ }^{\mathrm{c}}$, J.J. Li $^{\mathrm{c}}$, J. Zhang ${ }^{\mathrm{c}}$, A. Martín-Pérez ${ }^{\mathrm{a}}$, R. Martín-García ${ }^{\mathrm{a}}$, \\ X.X. Wang ${ }^{c}$, Y. Zhang ${ }^{c}$, M.H. Zhang ${ }^{b}$ \\ a Dept. of Petrology and Geochemistry, Faculty of Geological Sciences, Universidad Complutense, IGE-CSIC, 28040 Madrid, Spain \\ b Jiangsu Key Laboratory of Environmental Change and Ecological Construction \& College of Geography, Nanjing Normal University, Nanjing, 210097, China \\ c Key Laboratory of Western China's Environmental Systems (Ministry of Education) E' College of Resources and Environment, Lanzhou University, Lanzhou, 730000, China
}

\section{A R T I C L E I N F O}

\section{Keywords:}

Tianshui basin

Lake deposits

Mudflat

Calcretes

Eolian deposits

Neogene

\begin{abstract}
A B S T R A C T
The Tianshui Basin in central China contains a thick sedimentary sequence $(\sim 1400 \mathrm{~m})$ of continental deposits, Aragonian to Villafranchian (Miocene-Pliocene) in age. Intense Himalayan movements around the Paleogene/Miocene boundary triggered the uplift of mountain ranges around the Tianshui Basin, providing the deposition site for continental sediments. The sedimentary infill of the basin consists of four stratigraphic units (I to IV). This paper focuses on Unit II. Most of the accommodation space was occupied by Unit I, so during the sedimentation of Unit II, the morphology of the basin was relatively flat, promoting the development of wide distal fan/mudflat areas and wide shallow lakes. Deposits include: red mudstones, pedogenic and groundwater calcretes, reworked calcrete deposits, sheet-floods, fluvial channels, rippled sandstones/siltstones, ooidal/peloidal packstones, palustrine limestones, bioturbated marls and intraclastic limestones/marls. The characteristics and organization of the deposits indicate the gradual transition from alluvial to lake environments. Within the distal fan/mudflat, the deposition of reworked calcrete clasts as one of the most striking facies of the basin may be attributed to substantial recycling of calcrete levels and red clays. At the lake margins, the presence of ooids and palustrine limestones suggests the possibility of ramplike margins within different energy settings. The origin of some of the deposits of the basin's QA-I section is under discussion, and their consideration as eolian has been recently proposed. However, we believe this possibility is precluded by the characteristics of the deposits. Our proposal has important implications for revising the interpretation of Miocene paleoclimatic conditions in central Asia.
\end{abstract}

\section{Introduction}

The central areas of China contain a thick continental sedimentary sequence, the age of which spans from Aragonian to the present. The origin of these sediments has been the subject of much dispute and the reddish clay-silt sequence near Qinan (QA-I section) (Fig. 1), dated as $22 \mathrm{Ma}$, has been recently interpreted as eolian loess (Guo et al., 2002). This interpretation was based on field aspect, mineralogy, grain size and morphology. Indeed, the deposits of the QA-I section bear geochemical similarities with Quaternary loess (Guo et al., 2002). However, if these deposits of the Tianshui Basin are interpreted as eolian loess, this area would have represented a sizeable desert in central Asia at least since $22 \mathrm{Ma}$ ago. These authors propose that the desert was formed by the onset of winter monsoons in response to the uplift, 25 to $20 \mathrm{Ma}$ ago, of the Himalayas and southern margin of the Tibetan plateau. In previous works, the desertification of central Asia was dated around $8 \mathrm{Ma}$ at the eastern Loess Plateau (Sun et al., 1998; Ding et al., 1999) as indicated by the deposition of eolian Hipparion

\footnotetext{
* Corresponding author. Fax: +34 915442535.

E-mail address: alonsoza@geo.ucm.es (A.M. Alonso-Zarza).
}

Red Clay. This large discrepancy (14 Ma) in documented dust history is noteworthy. Despite these different interpretations, the sedimentology of these deposits remains largely unknown, making it difficult to contrast the two ideas.

In this paper, we focus on the sediments of the Tianshui Basin, a subdepression within the broad Longzhong Basin, central China (Fig. 1). Our aim was to conduct a stratigraphic study of the basin and a detailed analysis of one of the lithostratigraphic units (Unit II) that forms part of the sedimentary infill of this basin. We propose a closer look at the sedimentology of this unit, and discuss its eolian versus fan-lacustrine origin. Such an interpretation has implications for the timing and reconstruction of the history of both the Himalaya-Tibet uplift and the aridification of central Asia.

\section{Geologic setting and stratigraphy}

The Longzhong basin is a rhombic Cenozoic depression that covers over $100,000 \mathrm{~km}^{2}$, limited to the north by the left-lateral strike-slip Haiyuan fault, to the east and northeast by the Liupan Shan, to the southwest and west by the Tibetan Plateau, and to the south by the 


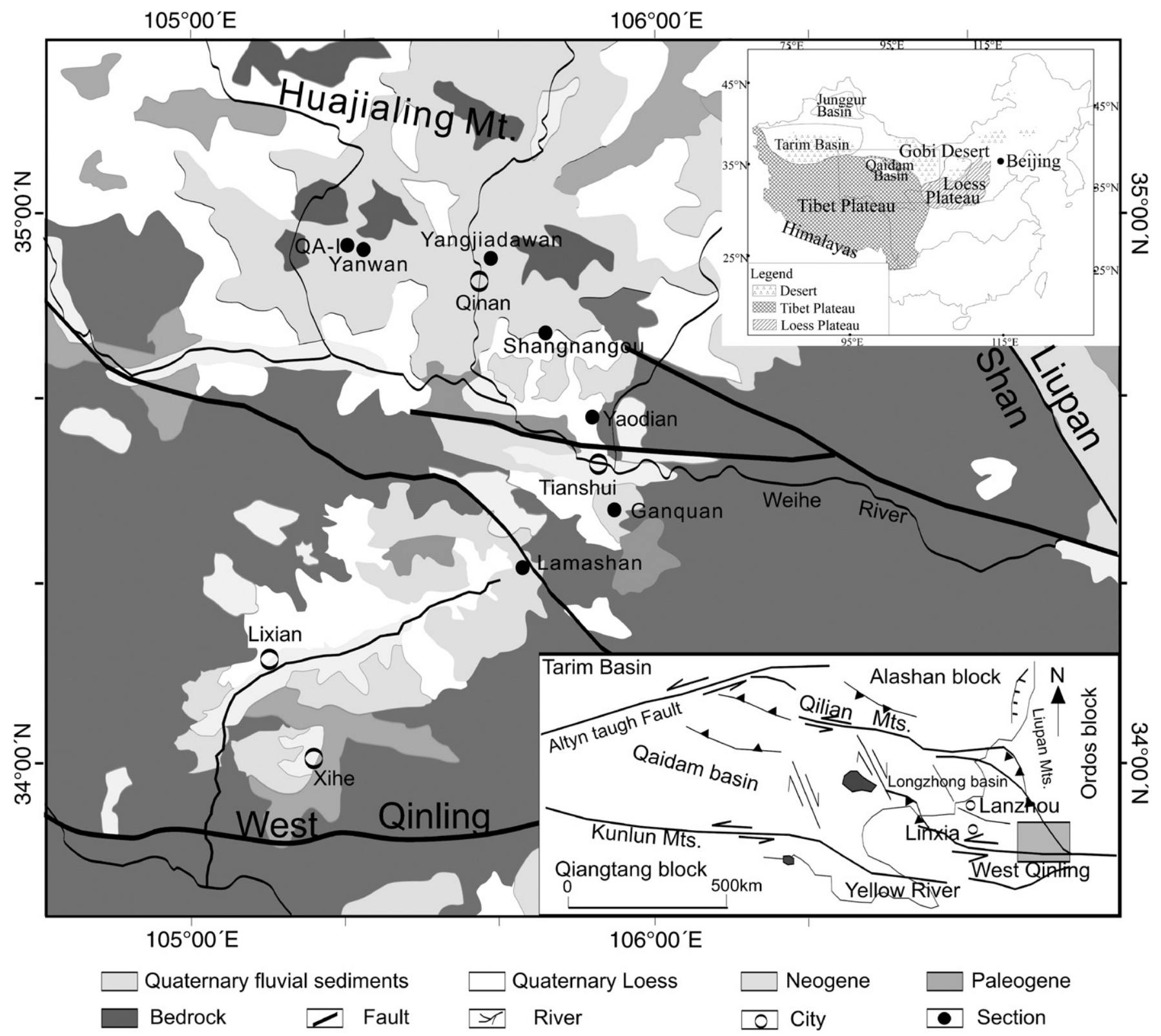

Fig. 1. Geologic setting and location map of the Tianshui Basin. Main sections in Fig. 3 are also indicated.

Western Qinling Mountain (Fig. 1). This large basin is divided into two sectors by a NW-SE trending highland, the Maxian Shan and Huajia Ling Mountain. The northern sector comprises the Lanzhou and Jingning basins and the southern sector includes the Linxia and the Tianshui basins; the latter two being separated by an upland composed of Paleogene conglomerates. The chronology of Tertiary succession in the Longzhong Basin has been well constrained by the magnetostratigraphy of the Tianshui (Li et al., 2006), Linxia (Li et al., 1997; Fang et al., 2003) and Lanzhou basins (Yue et al., 2001). A pervasive unconformity between Neogene/Paleogene sequences (Zhai and Cai, 1984) has been attributed to the influence of intense Himalayan movements (Shi et al., 1999), which triggered the uplift of mountains around both the Longzhong Basin and the Paleogene/ Neogene boundary. In the Tianshui Basin, the Qinling Mountain at its southern margin, sourced fans and fluvial deposits more than $1000 \mathrm{~m}$ thick. This is seen at Ganquan, where lower Neogene deposits $(\sim 1000 \mathrm{~m})$ are dominated by alluvial fan or braided fluvial conglomerates and sandstones and upper Neogene deposits $(\sim 400 \mathrm{~m})$ consist of gray-greenish lacustrine mudstones and marls. The thickness and grain size of these Neogene deposits rapidly decrease from south to north. In the north, mudstones around 300-500 m thick form a fringe around coarse clastic deposits. Major stream channels cut into the clay and discharge into the broad, central area of the basin. The Huajialing Mountain in the north contributes little relative to the vast material input from Qinling in the south, and the distribution of coarse terrigenous deposits is limited both in spatial and temporal terms.

Neogene sedimentation at the northern margin is dominated by mudstones and siltstones. Within the Neogene, four lithostratigraphic units can be distinguished (Figs. 2 and 3). Dating of the units has been based on the magnetostratigraphy of the Yaodian (Li et al., 2006) and QA-I (Guo et al., 2002) sections, and on mammal fossils from Yanwan aged as upper Vallesian and Turolian (Zhai, 1959, 1961). Unit I (Aragonian to lower Vallesian) comprises massive yellow-brown calcareous mudstones (or marls) interbedded with red siltstones, and fluvial channel and reworked calcrete deposits (Fig. 3). Thick, but finely laminated, sheet-flood siltstone deposits can be identified at the northern margin of the basin. The thickness of Unit I varies from 200 to $400 \mathrm{~m}$. Unit II (upper Vallesian to lower Turolian) is about $60-80 \mathrm{~m}$ thick. It consists of grey-green to white marls intercalated with red mudstones, forming distinctive color contrasts (Li et al., 2006). The 


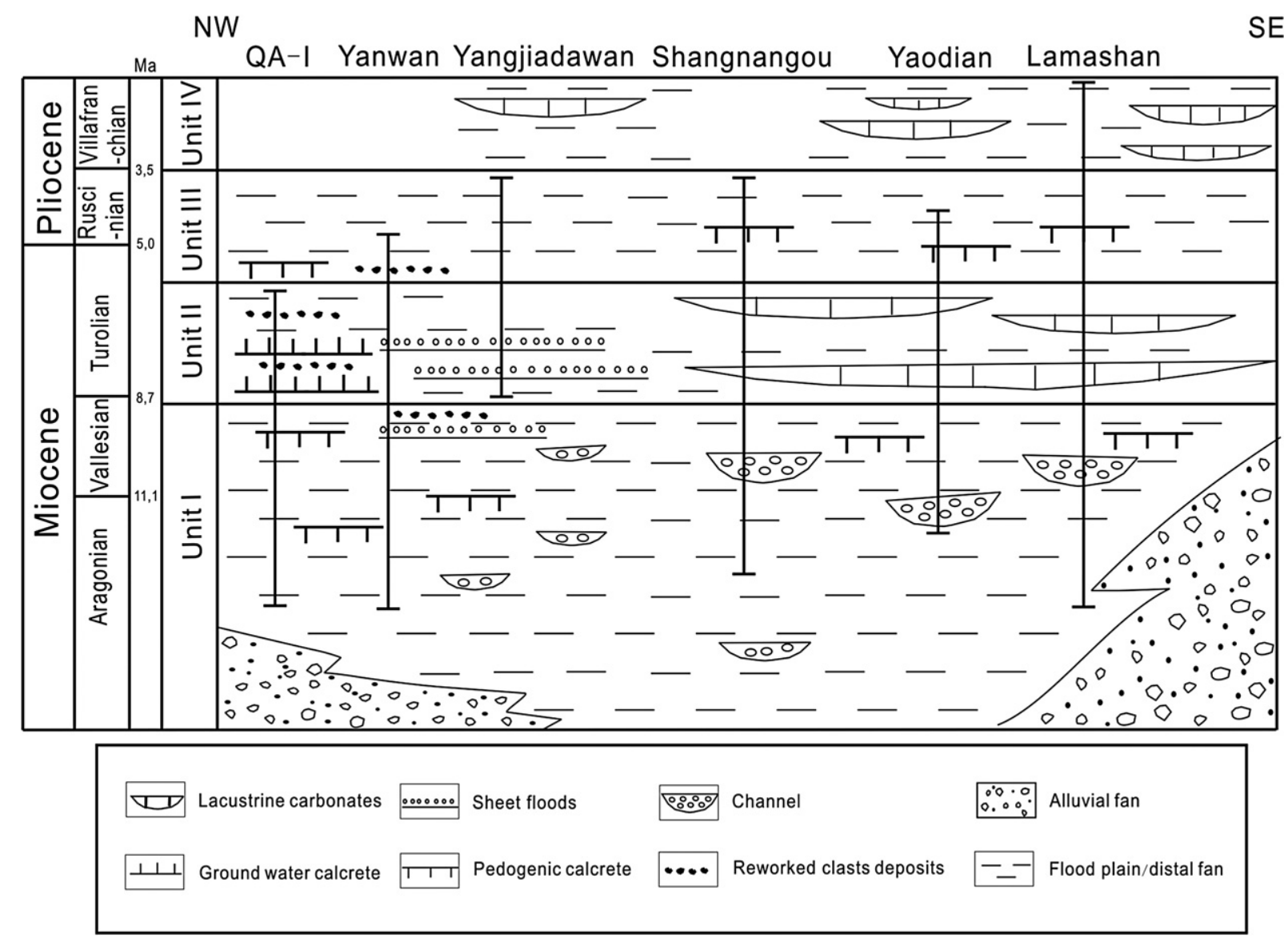

Fig. 2. Stratigraphy of the Neogene sedimentary record of the Tianshui Basin showing the four Neogene units.

marls can be traced from the south to the central basin, while northward they pass to sheet-flood siltstones. Here, we focus on the sedimentology of this unit. Unit III (upper Turolian and Ruscinian) is about $120 \mathrm{~m}$ thick and consists of massive red silty mudstones interbedded with yellow-brown to brown calcareous mudstones. Thin greenish marl layers occur occasionally and reworked calcrete clast lenses are common. Unit IV (Villafranchian) is up to $90 \mathrm{~m}$ thick and comprises massive or laminated lacustrine gray marls, organic-rich mudstones and local gypsum deposits.

\section{Sedimentology of Unit II}

The present study mostly describes the sections shown in Fig. 3. One of these sections (QA-I) has been examined by Guo et al. (2002). Our study focuses on Unit II, which shows the most prominent lacustrine sediments. The unit is very well bedded and varies in lithological and sedimentological terms. Across the entire basin, the transition from red clastic deposits to an alternation between red/ green clastics and carbonates is appreciable. In general, two main facies associations may be distinguished (Fig. 4).

\subsection{Distal fan/mudflat facies associations}

\subsubsection{Facies description and interpretation}

Fine red clastic sediments occur in beds from several $\mathrm{cm}$ to meters. These vary from fine sands to siltstones and commonly include micritic carbonate nodules. In other cases, especially at the base, they also include angular fragments of slightly lithified mudstones or limestones. These deposits are interpreted as typical distal fan/dry mudflat areas, which sometimes include reworked fragments of previous slightly lithified deposits.
Sparse to coalescent carbonate nodules occur on the red clay beds, which vary in thickness from $0.4 \mathrm{~m}$ to $2 \mathrm{~m}$. The carbonate nodules are micritic and include some silt/sand grains. Mottling, desiccation cracks and root traces are common. These nodular beds correspond to pedogenic calcrete profiles that only reached Stage III (Machette, 1985). Less developed calcretes show scattered nodules, whereas in Stage III, nodules are prismatic and coalesce. Laminar calcretes were not detected in these sections.

Massive to nodular carbonate beds show a very gradual transition from the underlying deposits and tops are sharp. They often resemble the pedogenic calcretes, the main difference being their massive appearance (Fig. 5A) and the dominance of non-biogenic features, since most beds show Alpha microfabrics (Wright and Tucker, 1991). Bed thickness is about $1 \mathrm{~m}$ and their main features are desiccation cracks and nodulization, cementation and replacement. The macro and micromorphology of these carbonates indicate they are groundwater calcretes. It is not completely clear whether at some points groundwater could have reached the surface to form palustrine deposits; these are commonly observed in distal areas of alluvial fans (Alonso-Zarza, 2003). Their presence, nevertheless, indicates a high water table.

Channels and lenses infilled with intrabasinal carbonate clasts (reworked deposits) are several decimeters thick and decimeters to hundreds of meters wide (Fig. 5B). Their base is commonly erosive. They consist of very angular $\mathrm{mm}$ to $\mathrm{cm}$ sized and angular clasts of micritic carbonates and/or mudstones (Fig. 5C). Micritic carbonates display internal desiccation cracks and small root traces. These deposits are clearly indicative of the reworking by flowing waters of the previous exposed mudflat/distal fan areas. Reworking of floodplains is a common process, and results in the recycling of previously deposited sediments (Marriott and Wright, 1996). In the present case, 


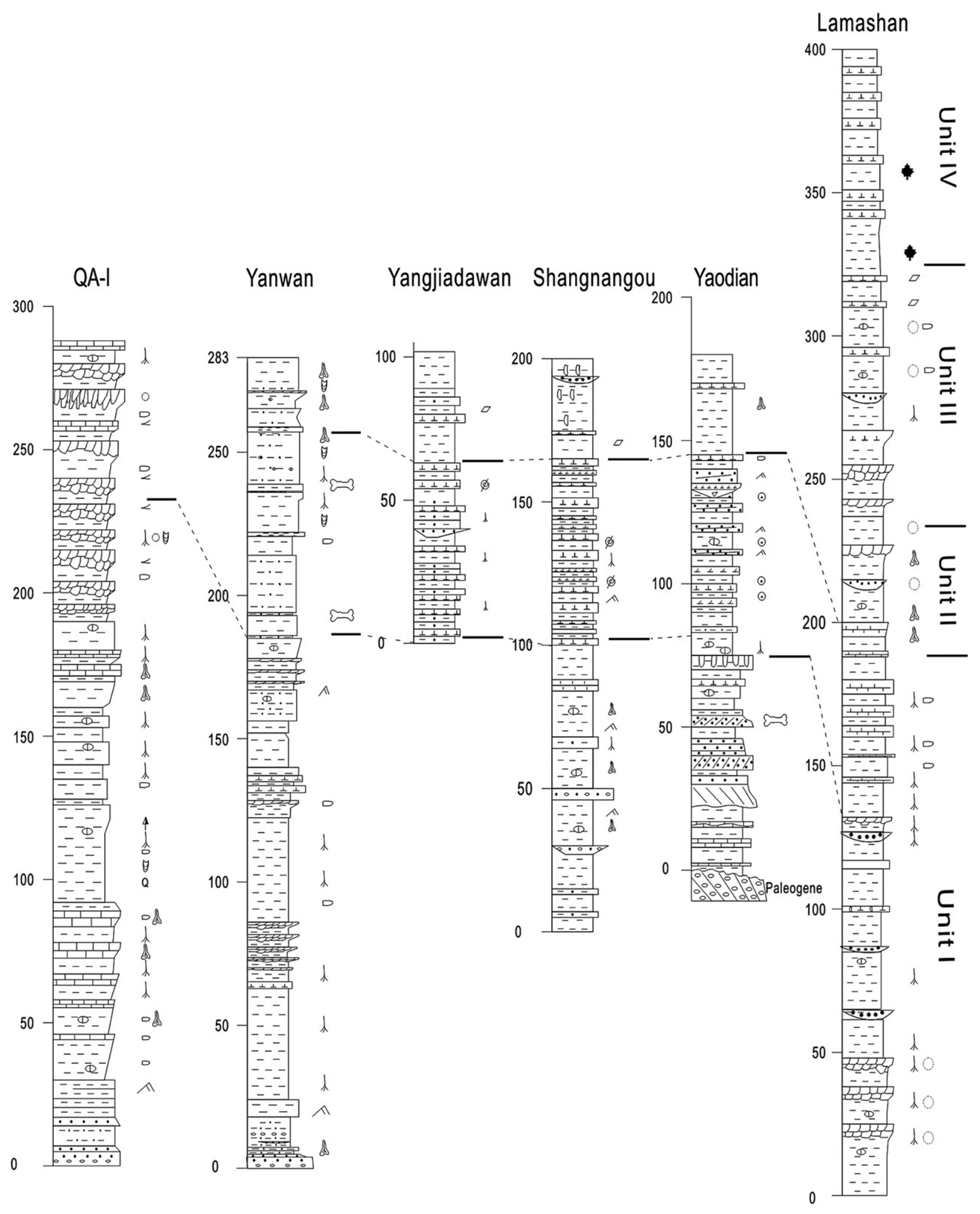

\begin{tabular}{|c|c|c|c|c|c|c|c|c|c|}
\hline$\because$ & Gravels & 因 & Nodular limestones & $\smile$ & Channels & $\odot$ & Coated grains & 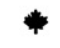 & Organic matter \\
\hline & & & & $\bullet$ & Reworked calcrete clast & 0 & Soft clasts & - & Hydrodinamic lamination \\
\hline$\because$ & Sands & ש & Palustrine limestones & 0 & Mottling & $\nabla$ & Gypsum & $\wedge$ & Ripples \\
\hline$\because-9$ & Laminated siltstones & $1 / 1$ & Calcitic/dolomitic marls & $\lambda \Delta$ & Roots/ calcified roots & $\infty$ & Sparse/Nertical carbonate nodules & $\varnothing$ & Gastropods \\
\hline- & Red/Green mudstone & & & $\theta$ & Bioturbation & $<$ & Dessication cracks & $\varepsilon$ & Mammal fossil sites \\
\hline
\end{tabular}

Fig. 3. Lithostratigraphic logs showing the most typical facies of the Neogene of the Tianshui Basin and their correlations, including the names of the units. 


\section{A DISTAL FAN/MUD FLAT}

I

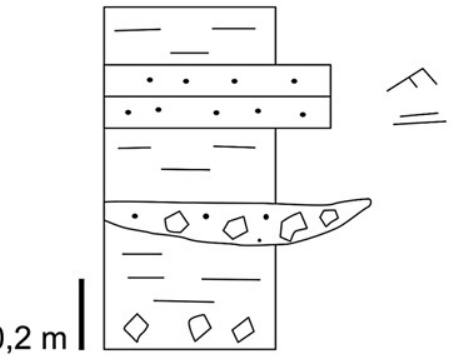

B LAKE MARGIN
II

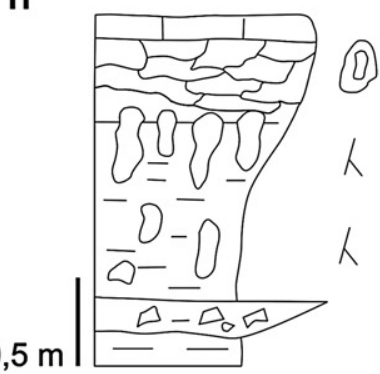

$0,5 \mathrm{ml}$

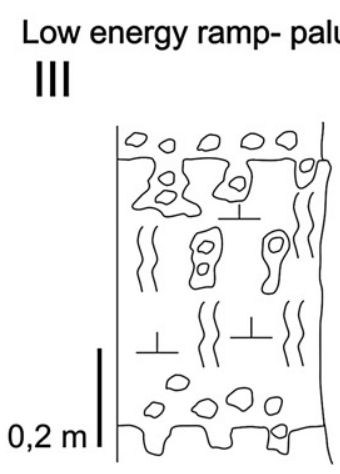

IV

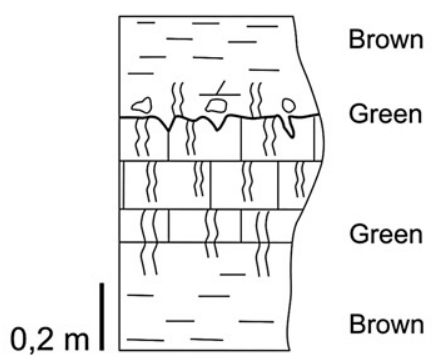

\begin{tabular}{|c|c|}
\hline$=$ & Clays \\
\hline$\because$ & Sheet-floods \\
\hline & $\begin{array}{l}\text { Sandstone channel with } \\
\text { reworked clasts }\end{array}$ \\
\hline & Reworked clasts \\
\hline & Pedogenic calcretes \\
\hline & Groundwater calcretes \\
\hline & Marls \\
\hline
\end{tabular}

20) Pseudomicrokarst

पा Palustrine limestones Root-bioturbation

${ }^{\circ} \odot$ Ooids

$\wedge$ Ripples

= Planar lamination

徐) Mottling

人 Root-tubes

Fig. 4. Facies associations of the distal fan/mudflat areas of Unit II.

High energy ramp- palustrine $\mathrm{V}$

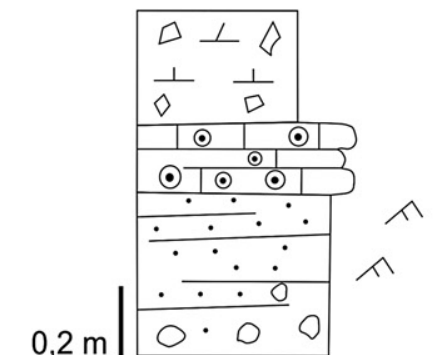

reworking was caused mostly by desiccation and subsequent transport of clasts by both sheet-floods and channels, similarly to the processes described in the Triassic and Permian of Minorca in Spain (Gómez-Gras and Alonso-Zarza, 2003).

Sheet-like silty to sandy deposits occur locally and are widely discerned near Yanwan, in the northern area of the basin. Of centimeter to decimeter thicknesses, these deposits are usually cemented by carbonates and interpreted as sheet-floods.

Channels infilled with extrabasinal clasts are erosive on the red mudstones. Clasts are usually sand-sized and include quartz, metamorphic rock fragments and intraclasts. Frequently, they also contain minor amounts of intrabasinal reworked clasts.

\subsubsection{Sedimentary environment}

The vertical organization of the facies points to two facies associations. The first (Fig. 4-I) consists mostly of red clays with interbedded sheet-floods and channels and represents usual deposition within mudflat areas. Sheet-floods probably arose because intense rainy events were not channelized over wide areas of the basin of low permeability (Hogg, 1982) due to their major mudstone contents. Immature calcretes (Stage II) sometimes formed and their record is also seen in the channels as reworked clasts. This facies association was intermediate between a medial fan to lake environment, and would be similar to a dry-mudflat (Eugster and Hardie, 1978) although in a nonevaporitic setting. In non-evaporitic settings, similar areas have been referred to as high mud flats (Ryder et al., 1976).

The second facies association (Fig. 4-II) consists of red mudstones with interbedded channels filled with intrabasinal clasts and ends with groundwater calcretes and palustrine limestones. This association reflects the gradual installation of a shallow water body within the mudflat area. Long periods of tectonic stability, common during the deposition of this unit, resulted in a decreasing sedimentation rate, which promoted the development of immature calcretes. Within these soils, carbonate precipitated initially around roots, and in the more mature calcretes this gave rise to vertically elongated nodules
(Esteban and Klappa, 1983). In most cases, the sequence is interrupted by the deposition of new fine sediments on the calcretes, inhibiting their development. In others, the progressive rise in the water table due to vertical aggradation of the floodplain (Bown and Kraus, 1987) interfered with pedogenic calcrete formation. The result is the superimposition of groundwater calcretes on pedogenic calcretes, and it is often difficult to distinguish the two or their boundary. Pedogenic calcretes commonly show more biogenic features, whereas groundwater calcretes are dominated by non-biogenic features such as dessication, mottling and nodulization (Wright and Tucker, 1991). If groundwater continues to rise, a shallow water body will form in a similar way to that described by Alonso-Zarza (2003) and micritic carbonate may precipitate to form palustrine limestones. Commonly identified cycles of pedogenic/groundwater calcretes in the presence or absence of a shallow water body probably reflect short scale climate changes, likely related to the adjacent sheet-flood deposits. Sinha et al. (2006) have attributed similar cycles in the Quaternary of the Ganga Plain to alternating rhythms of aggradation and degradation due to fluctuations between more arid or humid periods.

\subsection{Shallow lake facies associations}

\subsubsection{Facies description and interpretation}

Rippled sandstones/siltstones occur in beds about $40 \mathrm{~cm}$ thick and are gray to brown. They mostly include quartz grains and fragments of metamorphic rocks. Micas are also common as are larger $(\mathrm{mm})$ micritic clasts (intraclasts). Sand grains bear thin micritic coatings. Sparry calcite cements are common, filling in the intragranular porosity. These deposits formed in shallow and marginal areas of the lake, when clastic sediments were sourced by adjacent alluvial deposits.

Ooidal/peloidal packstones occur in centimeter-thick beds, usually white (Fig. 5E). The ooids are loose or embedded in micrite or calcite spar, are about $0.4 \mathrm{~mm}$ in diameter and show various types of nucleus. Some nuclei are quartz grains but others are fragments of clay clasts with some silt grains (soft clasts). The source area for these clasts is likely to 

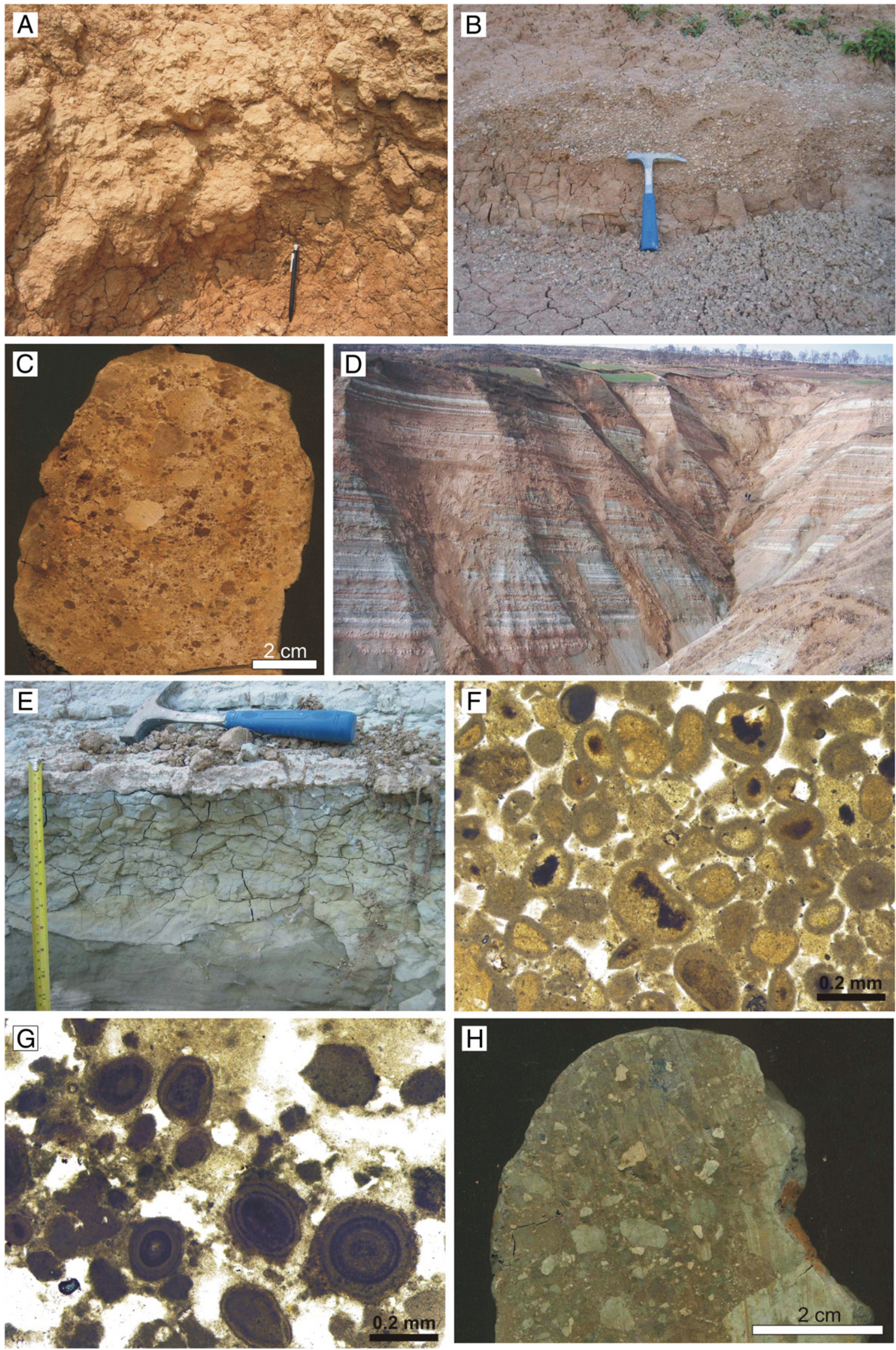

Fig. 5. A: Groundwater calcrete (QA-I section). B: Reworked calcrete deposits within a fluvial channel in the Lamashan section. C: Hand sample of the reworked deposits. Some white clasts arose from calcretes (both pedogenic and groundwater), whereas the darker clasts were sourced from the red mudstones of the mudflat. D: Lacustrine deposits showing interbedding of fine clastic sediments with marls/limestones, Yaodian Section. E: View of a thin bed containing ooids and peloids such as those shown in F and G. F: Thin section of an ooidal packstone in which the nuclei are fragments of aggregated fine clastic deposits. Envelopes are micritized. G: Thin section of an ooidal packstone, in which the ooids show clear concentric lamination. H: Hand sample of an intraclastic marl comprising fragments of indurated palustrine carbonates and also fragments of marls. 
be the adjacent mudflat area. Coatings vary in number from one to a few. They are regular and are formed either of transparent calcite crystals or of micrite, as a result of micritization of these grains, or may be initial micritic coatings (Fig. 5F, G). These ooids strongly resemble those described for the Triassic of England by Milroy and Wright (2002), and also have radial fabrics probably indicating an aragonite precursor that underwent micritization and dissolution, similarly to marine ooids. Lacustrine ooids from the Pliocene of Idaho also record an aragonite primary mineralogy and later transformation to LMC (Swirydczuk et al., 1979). Recent coated grains from Lake Geneva show some similarities to the ooids described here, since coatings are of varying thickness and have also been subjected to diagenetic processes such as aggrading neomorphism (Davaud and Girardclos, 2001). The features of the ooids of Lake Geneva indicate moderate hydrodynamic conditions. On occasion, ooidal limestones are interbedded within more peloidal limestones. The peloids are rounded and smaller $(0.1 \mathrm{~mm}$ in diameter $)$ and sometimes bear micritic coatings.

Micritic limestones and dolostones occur in beds $\mathrm{cm}$ to dm thick. They show features such as nodulization, mottling, desiccation cracks and pseudo-microkarst, and were therefore interpreted as palustrine carbonates (Freytet and Plaziat, 1982; Alonso-Zarza, 2003). In some cases, they include rounded and angular micritic grains formed as the result of grainification due to subaerial exposure (Alonso-Zarza et al., 1992). The filling of cavities formed either by roots or desiccation including both types of micritic grains. Ostracods are rare and some quartz and mica grains also appear.

Bioturbated calcitic or dolomitic marls are massive to slightly laminated and occur in dm-thick beds. They include some micritic carbonate nodules, millimeters in diameter, and cylindrical root tubes preserved in carbonate. They commonly show vertical cracks due to root bioturbation. The enlargement of cracks leads to the formation of breccias around the root traces. Frequent color changes are usually brown to green or vice versa. The marls are interbedded with any other deposit whether clastic or carbonate (Fig. 5E).

Intraclastic limestones/marls appear throughout the entire study area. They consist of fragments of marls, which are usually angular, mudstones or any type of limestone (Fig. 5H). Fragment size varies from sand to gravel. All fragments are sourced from nearby areas, either mudflat or shallow lake deposits, and may be red, white or green and embedded in a red or green matrix.

\subsubsection{Sedimentary environment}

The facies themselves and their vertical arrangement indicate three main facies associations representing different lacustrine environments. The first facies association (III, Fig. 4) is mostly comprised of marls. The sequences may have a basal term of intraclasts sourced from the lower most desiccated and exposed bed. The marls forming most of the sequence are highly bioturbated and show a number of desiccation and subaerial exposure features, such as pseudomicrokarst (Plaziat and Freytet, 1978), which is typically at the topmost of the sequence. These marls represent ponded zones of distal fan areas close to lake margins or the wet mudflat deposits of a wider lake environment; in either of these two cases they indicate marsh areas with an extensive vegetation cover and high water table. Similar marls have been described in Tertiary basins of Spain such as in the Calatayud Basin where they form part of climatically driven cycles (Abdul-Aziz et al., 2003).

The second association (IV, Fig. 4) reflects the gradual installation of a shallow water body on the bioturbated mudflat. Desiccation of the shallow lake is indicated by exposure features, but in other cases an increasing input of clays gives rise to the development of marsh areas. Color changes in the marls, from brown to green at the base and green to brown at the top, along with the lacustrine limestone constitute a complete cycle of installation and infill of a very shallow lake, or in other words, to rising and lowering of the groundwater table. The composition of the carbonates, commonly calcitic, but also containing some dolomite, indicates somewhat more concentrated waters in this part of the wet mudflat. A similar situation has been described in a number of basins such as the Uinta Basin (Ryder et al., 1976) or the Madrid Basin (Calvo et al., 1995), in which dolostones tend to occupy the mudflats. In these settings, evaporation concentrates the brines in near surface areas of the flats, which either promotes the direct precipitation of dolomite or replacement of previous carbonates (Ryder et al., 1976). Thus, dolomite did not form in the paleosols or inner lake areas. Also in this sequence, the presence of intraclasts and marly soft clasts are a clear indication of the subaerial exposure and later reworking of mudflat areas.

The third association (V, Fig. 4) consists of rippled sands/silts with interbedded ooidal packstones and ends with marls. Ooids seem to occur at high-energy lake margins. The classic example of this is the Tanganika Lake (Cohen and Thouin, 1987) in which ooids formed in wave agitated margins of the lake. Similarly, ooids of the Pliocene Glenns Ferry Oolite formed in a shallow agitated environment on a nearshore lacustrine beach, although ooid deposition occurred in deeper lakeward environments (Swirydczuk et al., 1979). In addition, Ryder et al. (1976) localized the ooids in small shoals forming an elevation that defined two areas within the lake system. Milroy and Wright (2002) described different ooids forming either in shoreface or oolithic shoal areas that may then be transported to different parts of the shallow lake system following different diagenetic paths. This particular lake system (Clevedon Oolite) formed at the foot of a strandplain dominated by sheet-flood deposits (Milroy and Wright, 2002). Ooids coexisting with rippled sands also indicates wave interaction in these higher energy lake margins. In short, these sequences indicate the occurrence of lacustrine marginal areas with higher energy levels, related either to sheet-flood events or wider areas. The topmost marls reflect the onset of lower (the most common) energy levels at the lake margins. No clear benches were observed indicating the relatively flat geometry of the lacustrine margins.

\section{Palaeogeography of the Tianshui Basin and paleoclimatic implications}

The presence of lake systems and the characteristics of their deposits are controlled mainly by tectonics and climate. The relative contributions of these factors and of others such as sediment supply, hydrology or source rocks are a matter of on-going controversy. Perhaps the clearest conceptual framework was proposed by Carroll and Bohacs (1999) and Bohacs et al. (2000). These authors consider that tectonics mostly controls the potential rate of deposition, whereas climate directly affects the sediment and water supply.

Sedimentation in the Tianshui Basin commenced with the deposition of Unit I; during this time, the Qinling Mountains (in the south) were very active, creating enough accommodation space for active alluvial fan sedimentation in these southernmost areas due to rapid subsidence in the thrust belt (Heller et al., 1998). The lacustrine deposits were reduced to the most central areas. This scenario fits well with an active foreland basin (Platt and Wright, 1991).

Unit 1 almost filled the available accommodation space and no new space was tectonically created. This prompted the formation of a relatively smooth topographic, almost flat, basin, with very wide mudflat areas in which Unit II was deposited. The flat topography (Fig. 6) determined that small changes in the water balance could cause drastic facies changes from lacustrine to mudflat environments across wide areas of the basin, similarly to the changes commonly observed in the "red bed" sequence of the Newark basin (Olsen et al., 1996). These changes include the gradual change from pedogenic to groundwater calcretes, or from groundwater calcretes to lake deposits. In addition, small water level decreases could have caused the subaerial exposure of wide areas of the mudflat and lake margins favoring the desiccation and reworking of sediments, as commonly described in both ephemeral saline lakes (Eugster and Hardie, 1978) and lake margin carbonate flats (Ryder et al., 1976). These sequences may be correlated with the sheet- 


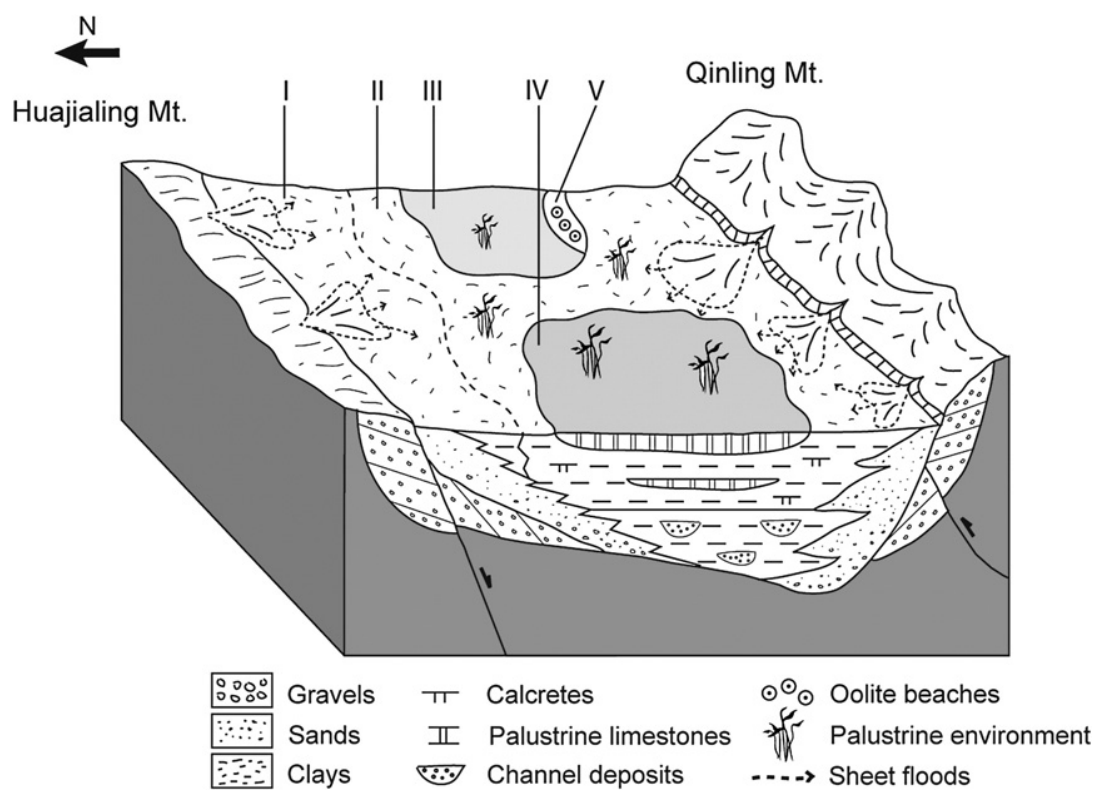

Fig. 6. Paleogeographic reconstruction of Unit II. The sketch illustrates the stage of expansion of shallow lakes following the long term denudation of the source area and infilling of the basin.

flood sequences that mark the events of heavy rains that could have both reworked the exposed areas and supplied the water, which depending on the area, gave rise either to the formation of groundwater calcretes or to the emersion of the water table, or gradually to both these events.

The rhythmical alternation of both clays and carbonates and color changes described occurred under conditions of a fluctuating lake level and different clastic inputs. These changes could be the result of climate changes modulated by the Earth's orbital parameters (Hays et al., 1976). A similar situation arises in the adjacent Linxia Basin (Fang et al., 2003) and the middle Miocene Calatayud Basin in NE Spain (Abdul-Aziz et al., 2004). Previous interpretations of precessional periodicities (19-23 ka) in the Eocene Wilkins Peak Member of the Green River Formation are now under discussion (Pietras and Carrol, 2006). These authors consider that cycles of expansion-contraction of Lake Gosiute may be autogenic and linked to the geomorphic instability of the drainage basin surrounding the lake. Pietras and Carrol (2006) propose even shorter length estimates for cycles in the basin center (1000 yr versus approx. $10,000 \mathrm{yr}$ ) due to possible hiatus, so there is no external driving mechanism to explain these short duration cycles. In short, more precise estimates of the time represented by each cycle and possible hiatuses are required to confirm these cycles were climatically driven.

The presence of ooids and rippled sands noted in the lake margin deposits, besides a water supply, indicates that some periods and/or areas of the lake margin showed higher energy. In the Great Salt Lake, it seems the ooidal facies formed in nearshore shoals of windy coastal areas (Eardley, 1938). From there, the ooids were then redistributed by wind and wave action to deeper lake areas. To date, this event has not been observed in our example. Interestingly, low and high energy lake deposits in a ramp dominated lacustrine system (Platt and Wright, 1991) can develop relatively closely in space and time, providing a further example of the relationship between low and high energy lake margins.

The paleogeographical model presented in this paper (Fig. 6) does not support the interpretation of the deposits of section QA-I as loess (Guo et al., 2002). The stratigraphic framework for the entire basin based on the good lateral correlation of all the sections including QA-I confirms the section correlates in space and time with basin-like sediments. Along with the sedimentological features of Unit II, this means that these deposits cannot be considered as eolian, although some extrabasinal clastic components could have been supplied by wind, thus explaining some of the geochemical similarities (Guo et al., 2002) between quartz grains from the Quaternary loess and section
QA-I. Very often, loess deposits are composed of a series of loesspaleosoil sequences (Wang et al., 2009), as recorded in the Quaternary of Illinois. In effect, the area examined lacks these sequences and shows more varied facies associations and arrangements including groundwater calcretes, reworked calcrete deposits or palustrine limestones. In addition, some of the clasts are really angular and coarse, strongly resembling reworked limestone nodules. All these features were commonly identified in the QA-I section and are difficult to interpret as eolian.

Paleoecological evidence from the periphery of interior Asia indicates moderate climate conditions during the early Miocene. Further, a $30 \mathrm{Ma}$-long record of a pollen assemblage from Linxia, $200 \mathrm{~km}$ west of Tianshui, indicates a prevailing grassland from 30 to 21.8 Myr ago that since the Early Miocene was replaced by forests ( $\mathrm{Ma}$ et al., 1998). Under such a climate turnover, proboscideans were able to migrate from Africa to Pakistan (Bugti strata) and to Lanzhou in the Early Miocene (Xie, 2004). The thriving Miocene fauna in central and northwest China point to a mosaic scenario of grasslands and mixed woodlands with abundant shallow lakes or swamps (Wang et al., 2003, 2007). This scenario is indeed consistent with our paleogeographical model (Fig. 6).

Around 8 Myr ago, a deterioration in climate, as reflected by a decline in forests at the expense of the spread of grasslands in the Linxia Basin (Ma et al., 1998), led to the deposition of Hipparion Red Clay on the central Loess Plateau (Sun et al., 1998; Ding et al., 1999). This arid event has also been inferred from an eolian dust flux rise in the North Pacific (Rea et al., 1998). However, climate deterioration at this time was insufficient to cause extensive loess deposits, or at least these were not recorded in the study area until the Quaternary. Much higher and longer-lasting eolian dust flux on the Loess Plateau and North Pacific began in 3.6 Ma (Liu, 1985; Rea et al., 1998). This persistent drying could be attributed to the uplift of the Tibetan Plateau and onset of northern hemisphere ice sheets (Rea et al., 1998; Li and Fang, 1999).

Both sedimentological and paleoclimatic data indicate that during Miocene times, the study area was not as arid as discussed by Guo et al. (2002) and that most sediments were deposited in alluvial and lacustrine environments. Although not really one of the aims of our study, our conclusions support the classical interpretation of the sediments of the Tianshui basin as alluvial and lacustrine. Thus, for the time being we are unable to put forward arguments in favor of aridification of Central China as far back as $22 \mathrm{Ma}$ ago. 


\section{Conclusions}

The Tianshui Basin in central China contains a thick sequence of continental Neogene deposits, the origin of which is widely discussed. The following conclusions may be drawn from our findings:

The stratigraphic record can be divided into 4 main stratigraphic units (I to IV), which may be correlated across the entire basin. The sedimentary record spans from the Aragonian to Villafranchian. As a result of the uplift of the Quinling Mountains, the sedimentation space available for the sedimentation of Unit I gradually became smaller.

Our sedimentological study focuses on Unit II of the central areas of the basin, where the accommodation rate was reduced. The unit was deposited in a combination of distal/fan mudflat and shallow lacustrine environments. Within lacustrine areas, two types of ramp-like margins sometimes co-existed in different parts of the basin. High-energy ooidal deposits commonly occurred in southern areas, whereas palustrine limestones (low-energy) were widespread throughout the whole basin. In most cases, both distal/fan mudflat and lacustrine deposits were very well bedded and showed clear alternation of the different facies. In mudflat/distal fan settings, alternations reflected the gradual rise in the water table, which sometimes led to the formation of shallow lakes on pedogenic + groundwater calcretes, followed by a new sedimentation event. In lakes areas, the cycles indicate lake expansion and desiccation. The facies and facies associations observed and particularly the presence of ooids and reworked calcrete clasts make it very difficult to interpret these deposits as eolian.

So far we have found no evidence suggesting that the aridification of central Asia starting as far back as $22 \mathrm{Ma}$ ago at the time of uplift of the Himalayas. On the contrary, our data point to semi-arid climate conditions, in agreement with published paleoecological data.

\section{Acknowledgements}

The authors thank Prof. Shi Y. F. for constructive suggestions, and Drs. Hui Z., Meng Q., Shu Q., Cui Q. and Liu Y., for their valuable help both in the field and laboratory. This study was supported by the National Basic Research Program of China projects Tibetan Plateau (2005CB422001) and NSFC (40721061). The Spanish group was supported by projects CGL2005-05953-C02-2/CGL2008-05584-C0202 and CCG07-UCM/AMB-2299. We also wish to thank, A.R. Soria and L.H. Tanner for their useful suggestions, Ll. Cabrera for his editing work, and A. Burton for revising the English version of the manuscript.

\section{References}

Abdul-Aziz, H., Sanz-Rubio, E., Calvo, J.P., Hilgen, F.J., Krijgsman, W., 2003. Paleoenvironmental reconstruction of a middle Miocene proximal alluvial fan to cyclic shallow lacustrine depositional system in the Calatayud Basin (NE Spain). Sedimentology 50, 211-236.

Abdul-Aziz, H., Van Dam, J., Hilgen, F.J., Krijgsman, W., 2004. Astronomical forcing in Upper Miocene continental sequences: implications for the Geomagnetic Polarity Time Scale. Earth Planetary Science Letters 222, 243-258.

Alonso-Zarza, A.M., 2003. Palaeoenvironmental significance of palustrine carbonates and calcretes in the geological record. Earth-Science Reviews 60, 261-298.

Alonso-Zarza, A.M., Calvo, J.P., García del Cura, M.A., 1992. Palustrine sedimentation and associated features - grainification and pseudo-microkarst - in the Middle Miocen (Intermediate Unit) of the Madrid Basin, Spain. Sedimentary Geology 76, 43-61.

Bohacs, K.M., Carroll, A.R., Neal, J.E., Mankiewicz, P.J., 2000. Lake-basin type, source potential, and hydrocarbon character: an integrated sequence-stratigraphic geochemical framework. In: Gierlowski-Kordesch, E.H., Kelts, K. (Eds.), Lake Basins through Space and Time: AAPG Studies in Geology, vol. 46, pp. 3-33.

Bown, T.M., Kraus, M.J., 1987. Integration of channel and floodplain suites. I Development sequence and lateral relations of alluvial paleosols. Journal Sedimentary Petrology 57, 587-601.

Calvo, J.P., Jones, B.F., Bustillo, M., Fort, R., Alonso-Zarza, A.M., Kendall, C., 1995 Sedimentology and geochemistry of carbonates from lacustrine sequences in the Madrid Basin, Central Spain. Chemical Geology 123, 173-191.

Carroll, A.R., Bohacs, K.M., 1999. Stratigraphic classification of ancient lakes: balancing tectonic and climatic controls. Geology 27, 99-102.

Cohen, A.S., Thouin, C., 1987. Nearshore carbonate deposits in Lake Tanganyika. Geology $15,414-418$.
Davaud, E., Girardclos, S., 2001. Recent freshwater ooids and oncoids from Western Lake Geneva (Switzerland): indications of a common organically mediated origin. Journal of Sedimentary Research 71, 423-429.

Ding, Z.L., Xiong, S.F., Sun, J.M., Yang, S.L., Gu, Z.Y., Liu, T.S., 1999. Pedostratigraphy and paleomagnetism of a $\sim 7.0 \mathrm{Ma}$ eolian loess-red clay sequence at Lingtai, Loess Plateau, north-central China and the implications for paleomonsoon evolution. Palaeogeography Palaeoclimatology Palaeoecology 152, 49-66.

Eardley, A.J., 1938. Sediments of Great Salt Lake, Utah. American Association Petroleum Geologists Bulletin 22, 1305-1411.

Esteban, M., Klappa, C.F., 1983. Subaerial exposure environments, In: Scholle, P.A Bebout, D.G., Moore, C.H. (Eds.), Carbonate Depositional Environments, vol. 33 American Association of Petroleum Geologists Memoir, Tulsa, OK, pp. 1-96.

Eugster, H.P., Hardie, L.A., 1978. Saline lakes. In: Lerman, A. (Ed.), Lakes: Chemistry, Geology, Physics. Springer-Verlay, New York, pp. 237-293.

Fang, X.M., Garzione, C., Van der Voo, R., Li, J.J., Fan, M.J., 2003. Flexural subsidence by $29 \mathrm{Ma}$ on the NE edge of Tibet from the magnetostratigraphy of Linxia Basin, China. Earth Planetary Science Letters 210, 545-560.

Freytet, P., Plaziat, J.C., 1982. Continental carbonate sedimentation and pedogenesis - Late Cretaceous and Early Tertiary of southern France. Contributions to Sedimentology 12 $213 \mathrm{pp}$.

Gómez-Gras, D., Alonso-Zarza, A.M., 2003. Reworked calcretes: their significance in the reconstruction of alluvial sequences (Permian and Triassic, Minorca, Balearic Islands, Spain). Sedimentary Geology 158, 299-319.

Guo, Z.T., Ruddiman, W.F., Hao, Q.Z., Wu, H.B., Qiao, Y.S., Zhu, R.X., Peng, S.Z., Wei, J.J., Yuan, B.Y., Liu, T.S., 2002. Onset of Asian desertification by 22 Myr ago inferred from loess deposits in China. Nature 416, 159-163.

Hays, J.D., Imbrie, J., Shackleton, N.J., 1976. Variations in the Earth's orbit: pacemaker of the ice age. Science 194, 121-1132.

Heller, P.L., Angevine, C.L., Winslow, N.L., Paola, C., 1998. Two-phase stratigraphic model of foreland-basin sequences. Geology 16, 501-504.

Hogg, S.E., 1982. Sheetfloods, sheetwash, sheetflow, or ...? Earth-Science Reviews 18, $59-76$.

Li, J.J., Fang, X.M., 1999. Uplift of the Tibetan Plateau and environmental changes. Chinese Science Bulletin 44 (23), 2117-2124.

Li, J.J., Fang, X.M., Van der Voo, R., Zhu, J.J., Conall, M.N., Cao, J.X., Zhong, W., Chen, H.L., Wang, J., Wang, J.M., Zhang, Y.C., 1997. Late Cenozoic magnetostratigraphy (11-0 Ma) of the Dongshanding and Wangjiashan sections in the Longzhong Basin, western China. Geologie en Mijnbouw 76,121-134.

Li, J.J., Zhang, J., Song, C.H., Zhao, Z.J., Zhang, Y., Wang, X.X., Zhang, J.M., Cui, Q.Y., 2006 Miocene Bahean stratigraphy in the Longzhong Basin, northern central China and its implications in environmental change. Science in China (D) 49, 1270-1279.

Liu, T.S., 1985. Loess and the Environment. China Ocean Press, Beijing. 400 pp.

Ma, Y.Z., Li, J.J., Fang, X.M., 1998. Pollen assemblage in 30.6-5.0 Ma redbeds of Linxia region and climate evolution. Chinese Science Bulletin 43 (3), 301-304 (in Chinese).

Machette, M.N., 1985. Calcic soils of southwestern United States. In: Weide (Ed.), Soil and Quaternary Geology of the Southwestern United States Special Paper Geological Society of America, vol. 203, pp. 1-21.

Marriott, S.B., Wright, V.P., 1996. Sediment recycling on Siluro-Devonian floodplains. Journal of the Geological Society 153, 661-664.

Milroy, P.G., Wright, V.P., 2002. Fabrics, facies control and diagenesis of lacustrine ooids and associated grains from the Upper Triassic, southwest England. Geological Journal 17, 35-53.

Olsen, P.E., Kent, D.V., Cornet, B., Witte, W.K., Schlische, R.W., 1996. High-resolution stratigraphy of the Newark rift basin (early Mesozoic, eastern North America). Geological Society of America Bulletin 108, 40-77.

Pietras, J.T., Carrol, A.R., 2006. High-resolution stratigraphy of an underfilled lake basin: Wilkins Peak Member, Eocene Green River Formation, Wyoming, U.S.A. Journal of Sedimentary Research 76, 1197-1214.

Platt, N.H., Wright, V.P., 1991. Lacustrine carbonate: facies models, facies distributions and hydrocarbon aspects. Special Publication International Association Sedimentologists $13,57-74$.

Plaziat, J.C. Freytet, P., 1978 Le pseudo-microkarst pédologique: un aspect particulier des paléo-pédogenèses développées sur les depots calcaires lacustres dans le Tertiaire du Languedoc. Comptes Rendués Academie Science Paris 286, 1661-1664.

Rea, D.K., Snoeckx, H., Joseph, L.H., 1998. Late Cenozoic eolian deposition in the North Pacific: Asian drying, Tibetan uplift, and cooling of the northern hemisphere. Paleoceanography 13, 215-224.

Ryder, T.R., Fouch, D.T., Elison, H.J., 1976. Early Tertiary sedimentation in the western Uinta Basin, Utah. Geological Society of America Bulletin 87, 496-512.

Shi, Y.F., Tang, M.C., Ma, Y.Z., 1999. Linkage between the second uplifting of the QinghaiXizang (Tibetan) Plateau and the initiation of the Asian monsoon system. Science in China (D) 42, 303-312

Sinha, R., Tandon, S.K., Sanyal, P., Gibling, M.R., Stuben, D., Berner, Z., Ghazanfari, P., 2006. Calcretes from a Late Quaternary interfluve in the Ganga Plains, India: carbonate types and isotopic systems in a monsoonal setting. Palaeogeography, Palaeoclimatology, Palaeoecology 242, 214-239.

Sun, D.H., Shaw, J., An, Z.S., Chen, M.Y., Yue, L.P., 1998. Magnetostratigraphy and paleoclimatic interpretation of a continuous 7.2 Ma late Cenozoic eolian sediments from the Chinese Loess Plateau. Geophysical Research Letters 25, $85-88$.

Swirydczuk, K., Wilkinson, B., Smith, G., 1979. The Pliocene Glenns Ferry Oolite: lakemargin carbonate deposition in the southwestern Snake River Plain. Journal of Sedimentary Petrology 49, 995-1004.

Xie, G.P., 2004. The Tertiary and local mammalian faunas in Lanzhou Basin, Gansu. Journal of Stratigraphy 28, 66-80 (in Chinese). 
Wang, X.M., Qiu, Z.D., Opdyke, N.D., 2003. Litho-, bio-, and magnetostratigraphy and paleoenvironment of Tunggur Formation (Middle Miocene) in Central Inner Mongolia, China. American Museum Novitates 3411, 1-31.

Wang, X.M., Qiu, Z.D., Li, Q., Wang, B.Y., Qiu, Z.X., Downs, W.R., Xie, G.P., Xie, J.Y., Deng, T., Takeuchi, G.T., Tseng, J.Z., Chang, M.M., Liu, J., Wang, Y., Biasatti, D., Sun, Z.C., Fang, X.M., Meng, Q.Q., 2007. Vertebrate paleontology, biostratigraphy, geochronology, and paleoenvironment of Qaidam Basin in northern Tibetan Plateau. Palaeogeography, Palaeoclimatology, Palaeoecology 254, 363-385.

Wang, H., Lundstrom, C.C., Zhang, Z., Grimley, D.A., Balsam, W.L., (2009). A Mid-Late Quaternary loess-paleosol record in Simmons Fram in southern Illinois, U.S.A. Quaternary Science Reviews 28, 93-106.

Wright, V.P., Tucker, M.E., 1991. Calcretes: an introduction. In: Wright, V.P., Tucker, M.E. (Eds.), Calcretes. . Ias reprint series 2. Blackwell Scientific Publications, Oxford, pp. 1-22.
Yue, L.P., Heller, F., Oiu, Z.X., Zhang, L., Xie, G.P., Oiu, Z.D., Zhang, Y.X., 2001 Magnetostratigraphy and paleoenvironmental record of Tertiary deposits of Lanzhou basin. Chinese Science Bulletin 46, 770-773.

Zhai, R.J., 1959. On a collection of Miocene mammals from eastern Kansu. Pleovertebrata et Paleoanthropologia 1,139-140 in Chinese).

Zhai, R.J., 1961. On a collection of Neogene mammals from Ching-an, eastern Kansu. Vertebrata Palasiatica 5, 262-268 (in Chinese)

Zhai, Y., Cai, T., 1984. The Tertiary system of Gansu province. Gansu Geology. People's Press of Gansu, Lanzhou, China, pp. 1-40 (in Chinese). 